\title{
Etika Berpakaian Pemustaka: Representasi Lifestyle Pengguna dan Cara Berpikir Kritis Pustakawan di Perpustakaan Menggunakan Ideological State Apparatus
}

\author{
Fauzan Hidayatullah ${ }^{1}$, Kadek Aryana Dwi Putra ${ }^{2}$, \\ Rosnani Abdul Rahman ${ }^{3}$ \\ ${ }^{12}$ Universitas Gadjah Mada Yogyakarta ${ }^{3}$ Universitas Negeri Yogyakarta \\ fauzanhidayatullah@mail.ugm.ac.id
}

\begin{abstract}
Dress ethics is an important factor that is accounted for by an individual in a community. Someone will judge us by our appearance including our dress code. In the library there are regulations regarding the prohibition of using sandals, T-shirts and must be neatly dressed which raises the arena of social class and identity. By using the Ethnographic approach we can understand a social and cultural life in a society scientifically. In this case, we consider the views of the people as the most important thing. The results of this discussion criticize things that should not be taken for granted and open the knowledge of librarians to think critically in managing a library as a source of information.
\end{abstract}

Keywords:Dress Ethics; Library; Librarian.

\begin{abstract}
Abstrak
Etika berpakaian merupakan salah faktor penting yang dipertanggungjawabkan oleh suatu individu yang terdapat dalam sebuah komunitas. Seseorang dapat menilai sifat dan karakter dari penampilan termasuk tata cara berpakaian. Dalam perpustakaan terdapat peraturan tentang larangan menggunakan sandal, kaos oblong dan harus berpenampilan rapih yang menimbulkan arena kelas sosial dan perbedaan identitas. Menggunakan pendekatan Etnografi seseorang dapat memahami sebuah kehidupan sosial dan budaya yang tertanam dalam suatu masyarakat secara ilmiah. Hal ini dapat menilai sudut pandangan masyarakat sebagai hal yang terpenting. Hasil dari pembahasan ini yaitu mengkritik hal-hal yang tidak semestinya diterima begitu saja dan membuka wawasan pustakawan untuk berpikir kritis dalam menegelolah sebuah perpustakaan sebagai tempat sumber informasi.
\end{abstract}

Kata kunci: Etika Berpakaian; Perpustakaan; Pustakawan 


\section{A. PENDAHULUAN}

Di masa kanak-kanak, masyarakat diajarkan untuk menghormati orang tua maupun sesama sesuai dengan nilai yang sudah tertatanam dalam masyarakat.Pada masyarakat umum terdapat suatu nilai-nilai prilaku yang diakui secara umum yakni etika.Beretika membantu seseorang dalam membangun hubungan antar manusia dalam kehidupan seharihari.Pengertian tentang etika merupakan salah satu bentuk kebiasaan,kebudayaan, moral, tatanan suatu sifat, serta tatanan perilaku tergantung dari daerah yang ditinggali. Etika berasal dari kata Yunani ethos, yaitu (ta etha) dalam bentuk jamak yang berarti "adat istiadat" maupun "kebiasaan" (Keraf, 1998). Hal ini mempengaruhi tentang sebuah nilai salah satunya dalam berbusana pada suatu daerah tertentu.Seseorang dapat mengukur dan menilai secara langsung kemampuan seseorang dari pakaian yang kenakan.Tidak dapat dipungkiri kenyamanan dalam memilih pakaian dan menggunakannya juga berpengaruh dalam meningkat kepercayaan diri pada saat berada dikelompok tertentu.Sebuah penampilan juga mencerminkan kepribadian seseorang dan berperan besar dalam menunjang kerir seseorang.Berpakaian yang benar sesuai dengan yang diharapkan merupakan salah satu hal yang tidak dipisahkan dari etika itu sendiri serta prilaku sifat seseorang juga menambah nilai busana dalam diri seseorang.

Pakaian merupakan salah satu kebutuhan primer manusia yang perlu dipenuhi dalam kehidupan sehari-hari di samping kebutuhan tempat tinggal dan makanan.Tanpa berpakaian orang-orang pasti mengatakan bahwa orang tersebut mengalami gangguan jiwa. Sehingga gaya berpakaian orang pasti berbeda-beda dengan yang lain bahkan seseorang mengganti pakaiannya 2 kali dalam sehari. Perbedaan budaya pada masyarakat juga mempengaruhi nilai-nilai berpakaian dimana pada masyarakat tertentu seperti orang-orang yang menggunakan pakaian mewah dan rapi dapan menyampaikan pesan sosial dan memberikan pesan sosial.

Dalam ruang lingkup perpustakaan tentang tata tertib berpakaian dalam perpustakaan Menurut Zeitthaml dalamSedarmayanti(2000) yang menyatakan bahwa tolak ukur kualitas pelayanan salah satunya dapat diukur menggunakan dimensi, yaitu tangibles (berwujud), bahwa tempat dan peralatan harus nyaman dan memberikan nuasnsa menarik serta petugas pelayanan senantiasa berpakaian rapi. Tidak hanya pustakawan larangan tentang pemustaka di anjurkan untuk tidak memakai sandal, kaos oblong, dan celana jeans dalam ruang lingkup perpustakaan sehingga membuat gerak pemustaka tidak leluasa untuk mengunjungi perpustakaan. Hal ini sudah berlangsung sejak lama terutama di Indonesia beberapa perpustakaan menerapkan hal tersebut sehinggapemustaka enggan untuk datang berkunjung ke perpustakaan.Salah satu fungsi perpustakaan yaitu 
mencerdaskan kehidupan bangsa, sehingga perlu sebuah pembaharuan peraturan yang diterapkan di perpustakaan.

Perpustakaan yang berfungsih untuk mencerdaskan anak bangsa mustinya tidak memberikan batasan dalam mencari informasi terutama dalam mengunjungi perpustakaan yang dibatasi oleh peraturan tentang etika berpakaian dalam ruang lingkup perpustakaan. Sehingga pemustaka yang tidak memenuhi aturan di perpustakaan diposisikan sebagai pihak yang tersubordinan.Ideology state apparatus dalam hal ini berperan dalam melihat bagaimana praktik budaya-budaya berkaitan langsung dengan sistem kekuasaan yang lebih luas yang terkait atau beroperasi melalui fenomenafenomena sosial.

Penelitian yang dilakukan oleh RetnoHendariningrum(2008) dalam Fashion dan Gaya Hidup: Identitas dan Komunikasi. Gaya kehidupan dan mode telah melekat serta tidak dapat terpisahkan dari masyarakat millenial.Itu tidak terlihat dari sampulnya tetapi esensinya.Kapitalisme tidak hanya mempengaruhi wanita saja tetapi kini juga dengan pria.Kapitalisme perlahan-lahan menaklukkan agama dan melakukan co-modifikasi simbol agama.

Gambaran kehidupan masyarakat Indonesia.(Ibrahim, 2007) dijelaskan bahwa masyarakat Indonesia berkembang sejalan dengan sejarah globalisasi ekonomi dan transformasi kapitalisme konsumsi yang ditandai dengan menjamurnya pusat perbelanjaan seperti mall, industri waktu luang, industri mode atau fashion, industri kecantikan, industri kuliner, industri nasuhat, industri gosip, kawasan hunian mewah, realestate, gencarnya iklan barang-barang super mewah, berlibur keluar negeri, hadirnya sekolah mahal, kegandrungan terhadap merek asing, makanan yang instan, telepon seluler dan serbuan gaya hidup melalui industri iklan pada televisi yang hadir setiap hari.Melalui pendekatan etnografi seseorang dapat dengan mudah ikut dalam arena yang yang sedang dikaji. "Ethnography as a Way of Seeing" adalah karakter dari penelitian etnografi. Etnografi sebagai cara untuk melihat kajian secara langsung terhadap kehidupan dan kebudayaan suatu masyarakat atau etnik, seperti adat istiadat, kebiasaan dalam masyarakat, perekonomian, hukum, seni, religi dan bahasa. Beberapa ahli berpendapat, Spradley (1980), Atkinson (1992), Wolcott (1997), etnografi adalah cara mempelajari dan memahami sebuah kehidupan budaya masyarakat. Etnografi berarti menjelaskan secara langsung mengenai kultur dan subkultur individu yang berada dalam masyarakat tersebut (Manan, 2014).

Etnografi adalah suatu metode khusus atau satu set metode yang dikembangkan dalam ilmu sosiologi sejak memasuki abad 20, mempunyai beragam bentuk sifat dan karakter, termasuk pastisipasi etnografi, mengetahui dan ikut serta dalam kehidupan seseorang dalam jangka waktu yang lama, melihat fenomena yang terjadi, mengengarkan yang dikatakan, 
bertanya berbagai hal, dan pada akhirnya mengumpulkan data apa saja yang dapat diambil.Pada perpustakaan seseorang etnografer juga dapat melihat kondisi di dalam perpustakaan dengan ikut bergabung dalam arena yang dijalani pihak subordian terhadap kekuasaan yang dijalankan kelas borjuis dalam peraturan yang terdapat di perpustakaan.

\section{B. HASIL DAN PEMBAHASAN}

\section{Peran Orang Tua dan Guru Dalam Membentuk Etika}

Di masa kecil anak-anak diajarkan untuk selalu berbuat baik, berbuat baik dalam artian mengikuti prilaku-prilaku yang telah tertatam dalam benak orang tua.Setiap anak di pandang sebagai individu yang menarik dan lucu meskipun prilaku mereka berbeda-beda.Tetapi berbeda dengan sekarang bahwa setiap aspek individu terbentuk dan dikondisikan menurut kebiasaankebiasaan yang berlakau di dalam lingkungan anak.Orang tua serta keluarga merupakan pendidikan pertama yang didapatkan oleh anak-anak yang memberikan dampak langsung kepada anak.

Pemberian nilai-nilai etika, moral, dan norma kepada anak-anak agar memiliki nilai positif di mata orang lain, nilai positif dalam masyarakat tergantung dari perbuatan, ucapan serta tingkah laku dalam berinteraksi di masyarakat. Jika seseorang melakukan sesuai dengan nilai-nilai yang berlaku dalam masyarakat dan diterima serta menyenangkan di lingkungan tersebut, maka orang tersebut dinilai mempunyai etika, moral, dan norma yang baik, begitupun sebaliknya. hal tersebut juga berpengaruh terhadap budaya yang dimiliki seseorang di wilayah tertentu bahwa budaya pada umumnya mengacu pada prilaku manusia yang hidup sebelumnya sementara yang lainnya menganggap bahwa budaya itu lebih banyak tergantung pada wilayah makna yang ada dalam diri manusia atau abstarksi prilaku.

Ideology sebagai pengalaman tidaklah palsu, ini merupakan salah satu aspek yang menjadi inti pandangannya dalam sebuah idiolog(Althusser, 1969). Budaya mengatur agar manusia dapat mengerti bagaimana seharusnya bertindak, bernyikapi sesuatu, dan menentukan sikap jika sedang berhubungan dengan orang lain. Meskipun ilmu pengetahuan sudah maju belum tentu budaya yang di jalankan telah maju, tetapi masi harus tergantung bagaimana hubungan mengatur capaian material tersebut.Sehingga bentuk hubungan kebudayaan yang dinamis dan terus berubah karena adanya hubungan produksi.

Pendidikan merupakan hak bagi semua warga negara Indonesia tanpa terkecuali. Setiap individu diwajibkan untuk menempuh pendidikan seperti dalam undang-undang, hal ini ditegaskan melalui Instruksi Presiden tentang Penuntasan Wajib Belajar Pendidikan Dasar Sembilan Tahun, dan diharapkan tuntas pada tahun 2004, bertujuan untuk berkembangnya potensi anak didik agar menjadi manusia yang beriman dan bertakwa kepada Tuhan Yang Maha Esa, berakhlak mulia, sehat jasmani, berilmu, cakap, kreatif, 
mandiri, dan menjadi warga negara yang demokratis dan bertanggungjawab. Arti penting pendidikan karakter agar mengoptimalkan setiap karakter yang baik dan positif menghilangkan yang negative seperti bersikap baik, berperilaku budi luhur, dan berakhlak menjadi kekuatan dan modal dasar pengembangan individu dan bangsa nantinya.

Kapitalisme tidak hanya mereproduksi ketrampilan tetapi juga berdiri tegak di atas aliran berpikiran bebas dan klasik yang nanti akan berguna untuk bekerja, seperti baca, tulis, dan juga beragam pengetahuan lainnya, tetapi kapitalisemejuga memberi ketundukan pada aturan-aturan pada kapitalisme, kaum elit maupun calon elit. Kapitalisme juga mereproduksi kekuatan untuk menundukkan para pekerjamelalui berbagai aparatus yang ada di wilayah suprastruktur.Aturan-aturan yang dibuat oleh pemerintah dalam pembentukan karakter siswa telah diterapkan sebagai fungsi pengelolaan masyarakat yang kompleks, maka dalam hubungan ini governance melibatkan relasi atau keterkaitan antara berbagai kekuatan dalam negara yang berperan penting dalam pembuatan partauran, yakni pemerintah.Kaum kapitalis melihat kebebasan sebagai sebuah kepentingan untuk membangun keserasian antara dirinya sendiri dengan masyarakat yang lain.

Pembentukan karakter dan pendidikan manusia dapat dimulai sejak dini, dari rumah, sekolah, dan kegiatan sehari-hari masyarakat dengan masyarakat lainnya, dengan demikian, tidak bisa hanya semata-mata dilakukan melalui pembelajaran pengetahuan, namun juga perlu melalui penanaman atau pendidikan nilai-nilai. Secara umum, kajian-kajian tentang nilai biasanya mencakup dua bidang pokok yaitu estetika dan etika (akhlak, moral, budi pekerti). Aspek dalam tulisan Marx yang dijadikan landasan untuk mencari tahu pemikiran-pemikiran yang tertuju pada pembahasan 'kesadaran palsu' Marx berpendapat tentang ide-ide yang dominan dalam masyarakat adalah ide para kaum borjuis (Barker, 2004).

Masyarakat diatur oleh undang-undang tentang wajib belajar selama 9 bulan.Masyarakat diwajibkan untuk mengikuti undang-undang yang dibuat pemerintah sebagai kelas borjuis atau kapitalis sehingga pihak orang tua terpaksa mengikuti peraturan tersebut. Dengan adanya undang-undang tersebut individu-individu masyarakat akan takluk dan tunduk dihadapan pembuat peraturan. Di samping teknik dan pengetahuan ini, anak-anakpun perlu mengetahui aturan bertingkah laku yang baik dengan tetap menjagaaturan moral, kewarganegaraan, profesional, yang makna sesungguhnya adalah seperangkat aturan yang menimbulkan respek di dalam peningkatan daya kerja, serta ketundukan kaum subordinan pada tatanan aturan yang telah dibangun oleh kelas dominan. Bagi Althusser, pendidikan bukan hanya melanjutkanidiologi kelas berkuasa yang membenarkan dan 
melegiminasi kapitalisme, tetapi juga membangun sikap dan prilaku yang dijalankan oleh kebanyakan kelas dalam pembagian kerja (Barker, 2004).

\section{Lifestyle Berpkaian dalam Agama Islam}

Menurut istilah, pakaian merupakan segala sesuatu yang digunakan pada tubuh seseorang dalam berbagai ukuran dan modelnya seperti baju, celana, kain, jubah, ataupun yang lain, sesuai kebutuhan seseorang dalam pemakainya untuk suatu tujuan yang bersifat pribadi ataupun umum. Berpenampilan indah artinya seseorang dapat memadukan pakaiannya agar terlihat anggun untuk dipandang.Bukan berarti menggunakan pakaian baru ataupun mahal.Namun, pakaian tersebut harus cocok paduannya, sesuai kebiasaan masyarakat setempat, asalkan tidak melanggar syariat yang dianut. Kata IbnAthir, Syariat adalah ketentuan agama dari Allah yang diwajibkan kepada hamba-Nya, artinya syariat merupakan Islam itu sendiri.

Kewajiban dalam menutup aurat bagi seorang muslim adalah pertanda ketaatan menjalankan hukum dan syariat Allah. Gaya busana yang Islami bagi kaum lelaki maupun perempuan berbeda, karena batasan aurat laki-laki dan perempuan berbeda. Allah SWT menurunkan seperangkat aturan yang di berikan oleh Rasul-Rasulnya mengenai tata cara berpakaian agar dapat membedakan antara laki-laki dan perempuan. Dalam kehidupan sehari-hari seseorang di wajibkan untuk menjaga penampilan dan memakai pakaian yang wajar karena dalam islam aurat merupakan bagian tubuh manusia yang tidak boleh dibuka dan dilihat oleh orang lain. Batasan aurat laki-laki antara pusar sampai lutut, sedangkan perempuan yang wajib ditutup adalah segenap bahagian tubuhnya, kecuali wajah dan dua telapak tangannya. Sebahagian ulama menambahkan dua telapak kakinya (Sesse, 2016).

Pada pra-kapitalis terdapat satu apparatus idiologi negara yang dominan yang memusatkan bukan hanya fungsi suatu religius, tetapi juga pendidikan, serta sebagian besar fungsi komunikasi dan budaya (Luis Althusser).Adanya perbedaan pendapat serta kepentingan tersembunyi yang biasa terjadi dalam kelembagaan tentang caraberpakain(lifestyle) bertentangan dengan beberapa peraturan yang telah di buat oleh pemerintah, tetapi di pihak lain agama juga berperan besar dalam etika berpakaian seperti yang terjadi disalah satu perguruan tinggi negeri di Yogyakarta tentang. Althusser included among state ideological apparatuses the schools, the family, religions and religious institutions, and the mass media. They worked less by power and politics (as did the RSAs) and more by ideology(Louis Althusser, 2014).

Larangan menggunakan cadar yang dikutip oleh (Tempo, 2018)Surat resmi pendataan mahasiswi yang bercadar adalah nomor B1031/Un.02/R/AK.00.3/02/2018. Proses pendataan dilakukan 28 Februari 
2018 dan telah mendapatkan 41 mahasiswi menggunakan cadar. Staf kampus menjelaskan bahwa, kampus telah membentuk tim konseling atau pendampingan bagi mahasiswi yang menggunakan cadar. Mereka akandiberi nasehat dan dibina dalam tujuh tahapan. Jika telah dilakukan pembinaan melalui tujuh tahapan namun tetap menggunakan cadar, mereka dipersilakan keluar dari kampus. Ketika sebuah hal yang berbau religius bertentangan dengan aturan yang dibuat oleh pihak dominan maka akan banyak kritikan yang akan terjadi terutama yang bertentangan dengan firman-firman tuhan. Maka ini yang di katakana oleh Althusseridiologi sebagai pengalaman tidaklah palsu karena dalam Islam wajibnya menutup aurat untuk tidak memperlihatkan ke siapapun kecuali mahramnya.

\section{Keseragaman Pakaian di Era Orde Baru}

Dalam dunia pendidikan di dunia barat pelajar dahulu tidak di wajibkan untuk menggunakan seragam yang sama untuk mengikuti proses belajar mengajar. Dimana Indonesia pun pernah menerapkan hal tersebut pada saat Indonesia berada pada masa kolonial Belanda. Tetapi setelah Jepang berhasil merebut bangsa Indonesia dari tangan Belanda, Jepang menanamkan ideologi-ideologi budaya yang di bawah dari sana seperti dalam melakukan proses belajar bangsa Jepang menyeragamkan pakaian pada murid-muridnya, sehingga saat dapat dibedakan antara murid bangsa Jepang dan bangsa pribumi yang hanya memakai baju biasa. Setelah bangsa Jepang angkat kaki dari Indoneisa ternyata Presiden Soeharto mengeluarkan surat keputusan dalam penyeragaman pakaian dalam proses belajar mengajar dan menentukan warna corak yang akan di gunakan pada rana pendidikan.

Kebijakan orde baru yang dengan sengaja mengatur beberapa kebijakan pemerintah baru terhadap pendidikan adalah sistem doktrinisasi yaitu sebuah sistem yang memaksa paham-paham pemerintah orde baru agar tertanam pada benak anak-anak yang masih duduk dibangku pendidikan. Doktrin-doktrin yang ditanamkan dari jenjang pendidikan sekolah dasar hingga perguruan tinggi. Sehingga, pendidikan dialihkan pada pengembangan militerisme yang militan sesuai dengan tuntutan kehidupan suasana perang dingin. Semua serba kaku dan berjalan dalam sistem yang otoriter. Akhirnya, pendidikan pada masa orde baru selalu mengarah pada penyeragaman, baik cara berpakaian, berpikir maupun tinhkah laku.

Hingga saat ini penyeragaman berpakaian dalam sebuah pendidikan masi berlanjut karena sudah menjadi sebuah kebudayaan yang di turunkan pada masa penjajahan jepang sehingga sudah tertanam dalam benak masyarakat bahwa dalam mengikuti proses belajar mengajar dalam rana pendidikan di wajibkan untuk membeli seragam sekolah agar dapat mengikuti proses belajar mengajar padahal ini merupakan idiologi yang di bentuk oleh kapitalis. Individuals are shaped by ISAs to believe that their 
conformity to the needs of capitalist class structures is something quite different, a life path freely chosen by an independent and autonomous subject. In Althusser's words, the individual within modern capitalist societies is interpellated by ISAs as "free" so that he/she "freely accepts subjection"'(Richard D. Wolff, 2004).

\section{Lifestyle Berpakaian}

Lifestyle merupakan gambaran buat orang yang memakai pakaian sesuai dengan seleranya serta menggambarkan tingkat nilai moral manusia dalam lingkungan masyarakat di sekitarnya. Gaya hidup merupakan sebuah seni yang di budayakan oleh setiap individu yang berkaitan dengan perkembangan zaman dan teknologi, semakin berkembangnya teknologi maka semakin bertambah juga cara berpikir masyarakat dalam penerapan gaya hidup manusia sehari-hari.

Akan tetapi, cara anak berpakaian dipengaruhi oleh pola pengasuhan orangtua. Mulai dari budaya, etika, hingga rambu-rambu berpakaian diajarkan di dalam keluarga.Sekarang ini, orangtua tidak cukup hanya dengan sekadar memberi tahu dan memberi contoh.Sebab perkembangan teknologi internet sudah sangat pesat dan memberikan pengaruh besar terhadap anak-anak saat mencari informasi.Semenjak berkembangnya globalisasi banyak budaya luar yang masuk di Indonesia yang membawa hal positif maupun negatif. Budaya barat telah mempengaruhi masyarakat dalam berbagai aspek kehidupan salah satunya cara berpakaian.

Bagi William (Shusterman \& Jameson, 1992) yang mengadopsi gagasan Baudrillard pascamodernisme terlibat dalam kesadaran yang dangkal tentang masa kini dan kehilangan pemahaman historis serta ekspresi dari sistem dunia multinasional atau kapitalisme akhir dan merepresentasikan gaya kultural kapitalisme akhir yang beroperasi pada ruang global baru. Walaupun orang-orang tua tetap menginginkan tidak lunturnya budaya berpakaian maupun etika dalam berpakaian dalam masyarakat tetapi manusia tidak dapat menolak perkembangan zaman sekarang ini sehingga anak-muda mau tidak mau pasti ikut berperan dalam perkembangan zaman tersebut termasuk mengikuti gaya-gaya berpakaian yang berasal dari dunia barat.Dampak dari perkembangan zaman pun membuat para anak muda menginginkan kebiasaan gaya hidup yang mereka inginkan dan dapatkan dari dunia barat meskipun apa yang mereka inginkan kadang tidak memikirkan etika dan nilai-nilai yang berlaku dalam kalangan masyarakat. Terdapat sisi baik dan sisi buruknya pula, sisi baik yaitu para anak muda dapat mengetahui perkembangan duia luar baik dari seisi teknologi, ekonomi dan sebagainya sedangkan sisi buruknya salah satunya yaitu mengikuti prilaku berpakain yang sebenarnya tidak sesuai dengan norma yang berlaku di masyarakat. 


\section{Idiological State Apparatus Kekuasaan melalui Media Teknologi}

Pada awalnya manusia saling bertukar informasi secara langsung dalam kehidupan sehari-hari, tetapi saat ini manusia semakin di manjakan dengan adanya teknologi perkembangan yang sangat pesat mempengaruhi kegiatan dalam masyarakat mau tidak mau harus mengikuti perkembangannya. Jika seseorang tidak dapat meggunakan teknologi maka di anggap tidak mampu atau gagal dalam mengikuti perkembangan zaman.

Dengan teknologi manusia mampu melihat apa yang sedang terjadi di dunia barat yang tidak dapat mereka kunjungi secara langsung, teknologi yang dipandang dapat dengan mudah mendapatkan dan mencari apa yang diinginkan karena serba teknologinya dunia sekarang ini. Teknologi media mampu mengantarkan seseorang kesuatu tempat tanpa fisiknya berada di tempat tersebut, ini menandakan bahwa media mampu melampaui ruang dan waktu.

Ideology sebagai pemahaman yang keliru tentang kondisi nyata eksistensi adalah palsu (Richard D. Wolff, 2004). Banyak orang yang beranggapan bahwa tanpa teknologi orang-orang tidak dapat berbuat apaapa. Tetapi tanpa dissadari seorang yang menggunakan teknologi media informasi tentang apa yang dicari akan secara otomatis oleh sistem yang dibuat oleh kapitalis. Kelas borjuis semakin memperkuat kekuatannya dalam bidang teknologi dengan mengadopsi anak-anak yang telah di mahir dalam teknologi bahkan menyekolahkannya sejak dini sesuai dengan peraturan yang berlaku bahwa seseorang diwajibkan sekolah 9 tahun.

Dahulu budaya yang begitu di agung-agungkan disetiap maysarakat tertentu akan pudar karena masuknya media teknologi di tunggangi oleh kaum borjuis. Terutama anak-anak muda yang sekarang sudah tidak dapat dihindari dari teknologi yang mempengaruhi prilaku serta gaya hidup yang telah banyak terkoneksi dengan budaya-budaya luar sepertu cara berpakaian yang secara etika dan budaya bahwa pakaian yang dikenakan oleh budaya luar itu tidak sesuai dengan budaya yang telah di kenal selama ini.

Ideologi bila dikatkan dengan konteks media, ideologi dapat memberi gambaran bagaimana peristiwadilihat dan diletakkan dalam tempat tertentu. MenurutMatthew Kiern sebagaimanayang dikutip oleh (Eriyanto, 2001), berita dalam media massa tidaklah dibangun dalam ruang hampa dan disebarkan begitu saja tetapi diproduksi dari ideologi dominan dalam suatu wilayah kompetensi tertentu. Kelompok berkuasa ini, seperti negara, pemerintah, pemilik media ataupun sejenisnya. Melalui media yang telah dipengaruhinya kelas subordinandapat menjadikan idiologi dominan yang merupakan representasi.

Media berperan untuk memproduksi dan mereproduksi narasi serta wacana yang dimiliki menjadikan ideologi kelas penguasa menjadi 
dominan.An ideology always exists in an apparatus, and its practice, or practices. This existence is material. The existence of the ideas of his belief is material in that his ideas are his material actions inserted into material practices governed by material rituals which are themselves defined by the material ideological apparatus from which derive the ideas of that subject (Sutopo, 2019).

Media dengan sengaja memproduksi kehidupan keseharian yang berada di budaya luar untuk diperlihatkan ke budaya lokal sehingga dengan secara tidak langsung masyarakat terpengaruh dan beranggapan bahwa seperti ini budaya yang sedang tren sekarang sehingga ikut serta dalam mengikuti perkembangan yang sedang terjadi diluar. Di perlukan peran orang tua untuk tidak melarang anaknya dalam mengenakan pakaian ataupun sesuatu yang diinginkan. Sebab mereka sedang dalam proses pencarian jati diri, anak muda zaman sekarang semakin dilarang malah semakin nekat. Anak zaman sekarang membutuhkan diskusi dengan orangtuanya saat proses pencarian jati diri. Di saat itu pula nilai-nilai positif bisa dimasukkan untuk memberi pemahaman kepada anak.

Perbedaan gender membuat perempuan selalu di pojokkan dalam hal berbusana bahwa perempuan yang menutup auratnya di katakana perempuan yang baik sedangkan yang memakai pakain terbuaka di anggap buruk. Tidak selamanya hal tersebut terjadi maka dari itu diperlukan cara berpikir kritis untuk tidak terlalu cepat mengambil sebuah kesimpulan tanpa disaring terlebih dahulu.

\section{Hegemoni yang Berlaku dalam Perpustakaan}
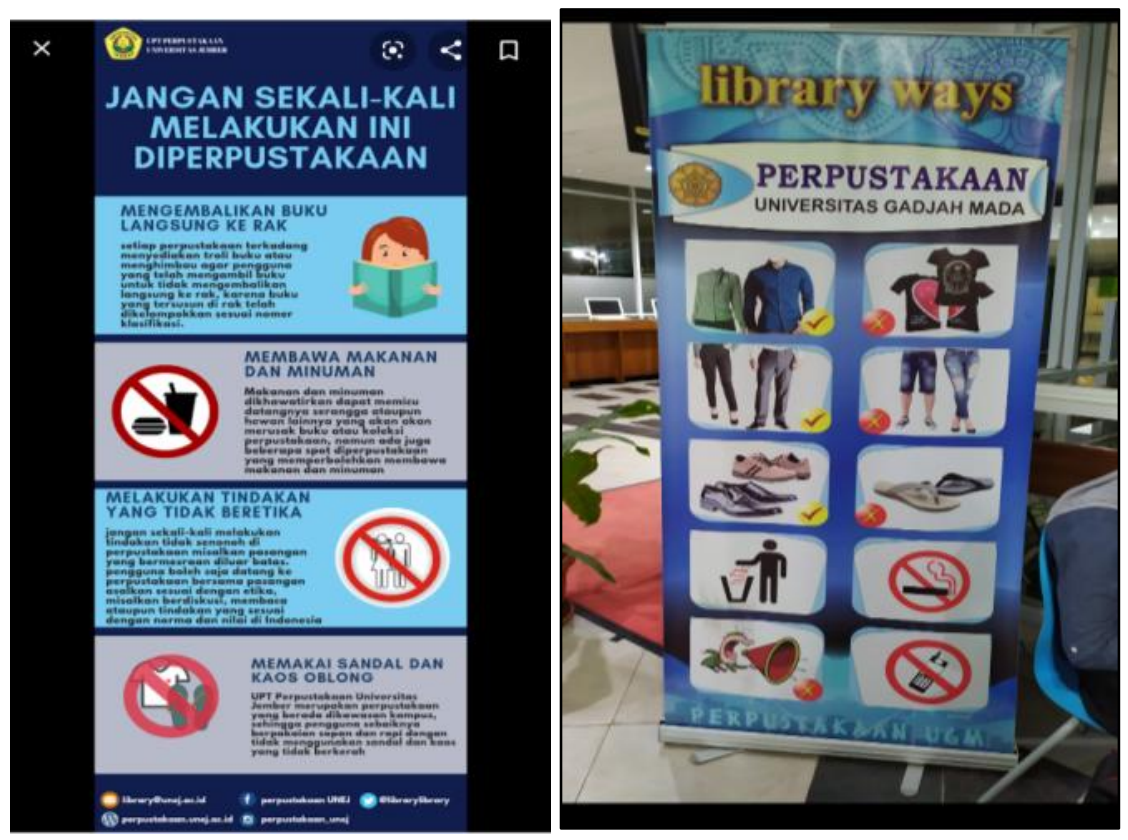
Dalam perpustakaan salah satu etika yang harus dijaga yaitu etika berpakaian. Dari dulu perpustakaan tidak memberikan keluasan oleh pemustaka untuk mengunjungi perpustakaan ketika memakai kaos oblong, celana jeans, dan sandal. Kini perpustakaan tidak lagi seperti dulu yang datang keperpustakaan menggunakan pakaian rapi, duduk diam focus belajar, dan tidak boleh membawa makanan. Karena fungsi perpustakaan sebagai kumpulan informasi yang bersifat ilmu pengetahuan, hiburan, rekreasi, penelitian dan tempat diskusi.Informasi juga telah dapat di akses tanpa berkunjung secara fisik ke perpustakaan, seseorang bisa mendapatkan informasi walaupun sedang dikamar hanya dengan mengunjungi websitewebsite dengan mudah di laman Google.

Model berpakaian akan berganti dari waktu ke waktu seiring perkembangan zaman. Dahulu manusia juga menggunakan pakaian tidak semewah sekarang karena belum mengenal namanya style tetapi kini budaya barat telah mempengaruhi budaya yang ada Indonesia dan apakah perpustakaan akan ketinggalan akan perubahan-perubahan yang berlaku sehingga tetap mempertahankan peraturan-peraturan yang diterapkan sejak dulu. Perpustakaan perlu merombak peraturan serta cara berpikir agar tetap dapat menarik pemustaka ke perpustakaan.

Perpustakaan akan kalah dengan penyedia informasi yang berbasis digital karena tidak di batasinya ruang gerak mereka dalam mencari informasi melalui teknologi sedangkan di perpustakaan sebagai tempat untuk mencerdaskan bangsa tetapi banyaknya aturan yang harus di lalui oleh pemustaka jika ingin ke perpustakaan. Ini di karenakan aturan-aturan yang dibuat oleh kelas dominan untuk membatasi ruang gerak kelas subordianan (pemustaka). Hegemoni adalah dominasi dan subordinasi pada wilayah yang distrukturkan oleh kekuasaan (Hall, 1998) dalam James Lull, 1998. Hegemoni merupakan alat yang digunakan untuk mendapatkan dan mempertahankan sebuah kekuasaan.

Menurut Van Dijk dalam (Eriyanto, 2009) mendefinisikan kekuasaan sebagai kepemilikan yang dimiliki oleh suatu kelompok orang, satu kelompok untuk mengontrol kelompok seseorang dari kelompok lain. The state apparatus not only has a very large part in its own reproduction; 1 it also, and above all, guarantees the general political conditions for the operation of the Ideological State Apparatuses by means of repression from the most brutal physical force to simple administrative orders and prohibitions, open or tacit censorship, and so on(Louis Althusser, 2014).

Di perpustakaan pemustaka dengan aturan tersebut menyetujui tentang larangan menggunakan kaos oblong untuk berkunjung di perpustakaan karena telah tertatam di kepalanya bahwa etika untuk masuk di perpustakaan yaitu menggunakan pakain rapi dan harus mengikuti perauranperaturan yang berlaku yang memang dengan sengaja dibuat oleh kelas 
dominan. Tetapi tidak ada juga pemustaka yang melanggar peraturan tersebut yang beranggapan bahwa ke perpustakaan itu tidaklah harus menggunakan pakaian yang rapi karena pemustaka berkunjung ke perpustakaan bukan untuk menapilkan kepribadian individunya agar dapat dilihat lebih bernilai dimata orang lain tetapi mereka berkunjung ke perpustakaan untuk mendapatkan informasi yang diinginkan sehingga melanggar aturan-aturan yang di buat oleh kaum bourjuis.

William (1973) terdapat unsur makna yang diyakini sebagai induk dan bersifat dominan. Proses penciptaan, peneguhan dan reproduksi makna dan praktikotoritatif ini, oleh Gramsci disebut dengan hegemoni. Secara teoretis dikenal ada tiga bentuk hubungan, yaitu dominasi, hegemoni, dan kooptasi. Dominasi adalah dicirikan oleh adanya pihak yang didominasi dan yang mendominasi.Hegemoni adalah hubungan dengan basis intelektual dan etika yang dapat diterima oleh rakyat yang diperintah. Sementara itu, kooptasi merupakan suatu proses menerima unsur-unsur baru dalam kepemimpinan atau pelaksanaan politik dalam suatu organisasi yang merupakan salah satu cara untuk menghindari terjadinya kegoncangan dalam stabilitas organisasi yang bersangkutan (Foucault, 1980). Hegemoni tidak saja terjadi antara negara namun dapat juga tejadi antara kelompok di dalam suatu negara.Hal ini yang tidak banyak disadari oleh masyarakat subordinan yang tetap mengikuti arus yang di buat oleh kelas dominan.

\section{KESIMPULAN}

Pustakawan sebagai sumber daya yang menggerakkan sumber daya lain dalam organisasi perpustakaan yang memungkinkan perpustakaan dapat berperan secara optimal didalam melaksanakan tugas pokok dan fungsinya, sehingga pustakawan menjadi ujung tombak keberhasilan dalam penyebarluasan informasi sehingga dengan mudah pemuastaka bisa mendapatkan informasi yang diinginkan di perpustakaan.

Untuk mewujudkan hal tersebut pustakawan tidak hanya focus dalam menjalankan tugasnya untuk menyebarkan informasi yang ada dalam perpustakaan tetapi juga di perlukan kemampuan berpikir krtitis yang memungkinkan pustkawan mampu menarik kesimpulan yang tepat, melihat persoalan-persoalan dari berbagai perspektif dan menghasilkan banyak alternative dalam memecahkan masalah yang sedang terjadi di perpustakaan.

Cara berpikir pemustaka juga kini telah berubah jadi bagaimana pustakawan mampu menganalisis perubahan prilaku pemustaka tidak hanya terfokus pada peraturan yang telah ada sejak dulu. Karena ketika pemustaka diberikan batasan-batasan dalam mencari informasi maka pemustakaakan mencari alternative lain untuk mendapatkan informasi dan fungsi perpustakaan sebagai penyadia informasi akan dikalahkan oleh teknologi yang juga menyediakan informasi yang lebih luas kepada pemustaka, 
Idiologi yang sudah tertanam sejak pustakawan bekerja di perpustakaan yaitu patuh kepada aturan dan atasan sehingga di perlukan keberanian untuk mengambil keputusan yang perlu ditingkatkan oleh pustakawan dalam mengambil keputusan seperti memberikan saran yang baik sehingga dpat mengubah peraturan-peraturan yang berlaku sejak lama dalam perpustakaan seperti etika berpakaian pemustaka untuk memasuki ruang lingkup perpustakaan karena perkembangan zaman yang telah berubah.

\section{DAFTAR RUJUKAN}

Althusser. (1969). for marx. Allen Lane.

Barker, C. (2004). cultural studies teori \& praktek. Kreasi Wacana.

Eriyanto. (2001). Analisis Framing: Konstruksi Ideologi dan Politik Media. LkiS Yogyakarta.

Eriyanto. (2009). Analisis Wacana. LkiS Yogyakarta.

Foucault, M. (1980). Power/Knowledge: Selected interviews \& other writings 1972-1977 Michel Foucault. In PowerKnowledge Selected Interviews and Other Writings 19721977.

Hall, S. (1998). james lull Media, Komunikasi, Kebudayaan. Suatu Pendekatan Global. Yayasan Obor Indonesia.

Hendariningrum, R., \& Edy Susilo, M. (2008). Fashion dan Gaya Hidup: Identitas dan Komunikasi. Ilmu Komunikasi.

Ibrahim. (2007). Budaya Populer sebagai Komunikasi. Jalasutra.

Keraf, A. S. (1998). Etika Bisnis. Kanisius.

Louis Althusser. (2014). On the Reproduction of Capitalism: Ideology and Ideological State Apparatuses. Verso.

Manan, A. (2014). Akuntansi Dalam Perspektif Budaya Jawa : Sebuah Study Etnografi Pada Pedagang Keliling Di Kota Semarang. Jurnal Ilmu Manajemen Dan Akuntansi Terapan (JIMAT), Volume $5 \mathrm{~N}$.

Richard D. Wolff. (2004). Ideological State Apparatuses, Consumerism, andU.S. Capitalism: Lessons for the Left. EconomicsDepartment Working Paper Series.

Sedarmayanti. (2000). Restrukturisasi dan Pemberdayaan Organisasi untuk Menghadapi Dinamika Perubahan Lingkungan. Masdar Maju. 
126 | TIK ILMEU: Jurnal IImu Perpustakaan dan Informasi, vol. 4, no. 2, 2020

Sesse, M. S. (2016). Aurat Wanita dan Hukum Menutupnya Menurut Hukum Islam. Jurnal Al-Maiyyah.

Shusterman, R., \& Jameson, F. (1992). Postmodernism, or, the Cultural Logic of Late Capitalism. The Journal of Aesthetics and Art Criticism. https://doi.org/10.2307/431237

Sutopo, O. R. (2019). Memahami cultural studies melalui konsep ideologi.

Tempo. (2018). UIN Sunan Kalijaga Yogya Larang Mahasiswi Bercadar.

William. (1973). Base and Superstructure in Marxist Cultural Studies Theory. New Left Review. 